\title{
エアバッグにおける緩衝特性に関する研究*
}

\author{
鮑 力 民*1, 西 城 英 莉*2, 銭 丹 娜*3 \\ 高 寺 政 行*1, 剱 持 潔*1
}

\section{A Study on Shock Absorbing Properties of Airbags}

\author{
Limin $\mathrm{BAO}^{* 4}$, Eri SAIJO, Danna QIAN, \\ Masayuki TAKATERA and Kiyoshi KEMMOCHI \\ ${ }^{* 4}$ Faculty of Textile Science and Technology, Shinshu University, \\ 3-15-1 Tokida, Ueda-shi, Nagano, 386-8567 Japan
}

\begin{abstract}
The promise of airbags for crew protection when automobiles collide has been realized. In previous airbag development, the prevailing purpose has been to protect the lives of the automobile's crew. It is necessary to understand in detail, as basic data, the impact of the airbag upon the crew, the crew's physique, and the specific accident situation, in order to minimize injuries due to airbag inflation for various accident situations and crews. There are two kinds of impact contact phenomena between the airbag and the crew. One occurs when the airbag is inflated then contacts the crew. The other occurs when the crew collides with the already inflated airbag. We focused our attention in the latter case in this research, designing an experiment apparatus based on a model of the airbag and the crew. The impact force is measured when the airbag contacts the crew under various conditions. The shock-absorbing characteristics of the airbag depend on the fabric's mechanical properties and contact conditions.
\end{abstract}

Key Words: Impact Load, Fabrics, Airbag, Evaluation, Inflation, FEM, Mechanical Properties, Shock Absorbing

\section{1. 緒 論}

乗用車用の各種エアバッグの開発により, 車両衝突 時の乗員保護効果は確実に向上している. 衝突事故に おける乗員死亡の軽減を実現する一方で，エアバッグ 展開が原因となる負傷例も報告されている(1) (3). そ こで, エアバッグ展開によるけがを軽減するため, 乗 員に対するエアバッグの攻撃性について詳しい研究が 必要である. 前報では, エアバッグが高速展開する際 の衝撃力の測定とシミュレーション方法を提案し, そ れを利用して, 衝撃力とエアバッグの織物の力学特性, 各影響因子との関係を明らかにした(4)(5).

一方, 歩行者を保護するエアバッグの開発も盛んに 行われている。硬い車体との間に展開されたエアバッ グにより, 歩行者の負傷を軽減させる効果がある。ま た, 事故時, 車内に展開されていたエアバッグは人間 が車体との 2 次, 3 次衝突による衝撃力を緩和し, 緩 衝効果を果たしている。

\section{構造材料の緩衝特性に関する研究は多く行われてい}

\footnotetext{
* 原稿受付 2008 年 4 月 15 日.

*1 正員, 信州大学瀻維学部(严386-8567 上田市常田 3-15-1).

*2 信州大学繊維学部.

*3 信州大学大学院工学系研究科

E-mail : baolimi@shinshu-u.ac.jp
}

て，その成果は [衝撃と振動工学ハンドブック $]^{(6)} に$ 纆められ, 緩衝特性を利用した構造が各分野で応用さ れている. 著者ら ${ }^{(7)}$ はゴルフシャフト, ロボットアー ム, 自動車のプロペラシャフト等の構造材料として用 いられた FRP 積層円筒の緩衝特性に対して, FRP 積 層理論を応用し, FRP 積層円筒の緩衝特性と繊維配 向角の関係を実験と数值計算で明らかにした。深谷 ${ }^{(8)}$ は墜落災害における被害を少しでも減らすために開発 された墜落防護用エアバッグについて，エアバッグを つけたダミーの落下試験を行い，エアバッグによる頭 部への衝撃の緩和を確認し，エアバッグの適用範囲 (高さ, 体重)についても検討した。しかし, 各パラメ 一夕(材料, 圧力, 衝撃物の質量など)によるエアバッ グの緩衝特性への影響に関する基礎研究は見当たらな く，未知なことがまだ多い.

事故や乗員のさまざまな状況に対応し，できるだけ エアバッグ展開によるけがを軽減させるため基礎デー タとして, 本報は, 展開されたエアバッグの緩衝現象 について，エアバッグと乗員が接触した際の衝撃力に 注目し，エアバッグと乗員をモデルとした実験装置を 考案・作製し，それを利用してさまざまな接触条件に ついての衝撃力を測定する。また数値計算による各衝 突条件下での衝撃力導出を試みる.それより緩衝のメ 
カニズムと各影響因子を検討する.

\section{2. 実験装置と試料}

$2 \cdot 1$ 実験装置と方法エアバッグの緩衝特性を 測定するために, 図 1 の装置を試作した。

エアタンクの前面にサンプルを固定する装置を設け ている．図 2 はその固定部分の写真である。サンプル の織物を $\mathrm{O}$ リングが取り付けられた板で挟みこみ， 6 本のボルトで固定する。圧縮空気によりこの織物を展 開させる．タンク中の圧力は圧力センサー [共和電業 (株) PGM-10 KC］で測定し, エアバッグ内の圧力と する。エアタンクは直径 $100 \mathrm{~mm}$, 深さ $120 \mathrm{~mm}$ の円 柱形で最大容積は $9.42 \times 10^{5}\left[\mathrm{~mm}^{3}\right]$, 織物の展開面の 直径は $100 \mathrm{~mm}$ である.タンク内に厚さ $10 \mathrm{~mm}$ の円 形アクリル板を複数枚入れることにより容積を調整す ることができる。この容積の変化をエアバッグにおけ る容積の変化とするまた本研究では，エアタンク前 面の金属円周部分に発泡スチロールシールを取付けて 反発後の金属ブロックの再衝突によるセンサの破壞を 防いでいる。

衝撃力の測定について, 圧電式加速度トランスデュ 一サを利用することが普通であるが，エアバッグの緩 衝特性では，周波数が低いため，図 3 のようなひずみ ゲージ式のセンサを作製し，その衝撃力を測定するこ ととした．金属ブロックと衝撃接触部との間にひずみ ゲージを取付けたりん青銅板を挟む。衝撃力による板

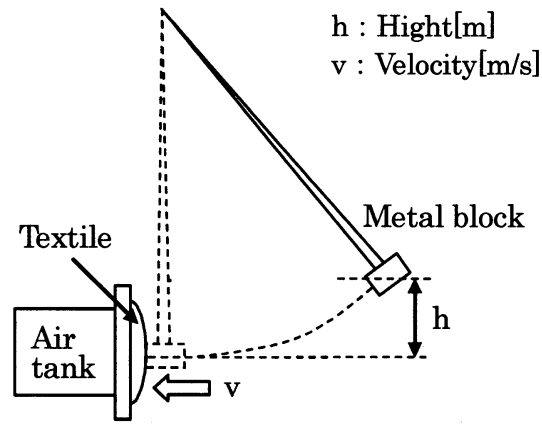

Fig. 1 Experimental equipment
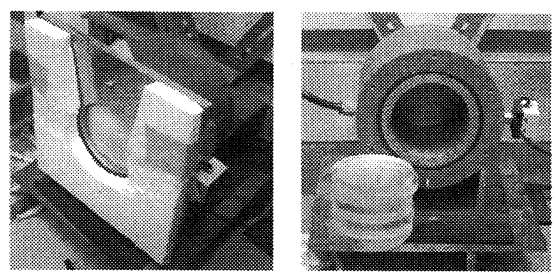

Fig. 2 Air tank and acrylic disk
の曲げ変形をひずみゲージとデータ収集システム (KEYENCE. Co. Lte NR-500)より収集し, パソコン に取り込む. 衝撃接触部と織物との接触面の直径は $20 \mathrm{~mm}$ である. 図 3 に示したように，2個のおもりを ねじで固定し, 取り外しによって金属ブロックの質量 調整が可能である. 織物との接触部, 金属ブロックお よびおもりにはアルミを用いており，質量はセンサ部 分と織物との接触部を含めた金属ブロック全体が $0.150 \mathrm{~kg}$ であり，おもりはいずれも $0.075 \mathrm{~kg}$ である. センサーの固有振動数は $2 \mathrm{kHz}$ 程度で, 本研究に応 用できると考える。

金属ブロックの重さ，接触部の径と織物サンプルの 径の比, エアタンクの容積などの選定は, 運転席エア バッグのデータを参考し, その容積の 1/125 のスケー ルで作製した。

実験を以下の手順で行う。

（1）サンプルの織物をエアタンクの前面に装着す る.エアコンプレッサで圧縮した設定圧力の空気を, エアタンクに流し込み, 織物を膨らます。レギュレー タでエアタンク内部圧力を調整する。

（2）金属ブロックを持ち上げて所定の高さから静 かに開放し，織物の展開面に衝突させる。

（3）織物との接触によるセンサーの出力はデー夕 収集システムより収集し、コンピュータに取込む。サ

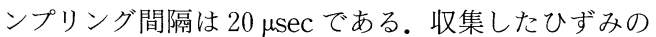
データを荷重に変換し, 衝撃力とする.

以上の手順で, 以下の条件を系統的に変化させ, 各 条件において 5 回ずつ実験を行う。

衝突速度：3.43, 3.96, 4.43,4.85, $5.24[\mathrm{~m} / \mathrm{s}]$

タンク内部圧力 : $0.1,0.2,0.3,0.4,0.5[\mathrm{MPa}]$

センサ質量：0.150,0.225,0.300 [kg]

タンク容積: $2.36 \times 10^{5}, 4.71 \times 10^{5}, 7.07 \times 10^{5}$,

$9.42 \times 10^{5}\left[\mathrm{~mm}^{3}\right]$

$2 \cdot 2$ 試料 今回実験に用いた試料は豊田紡織

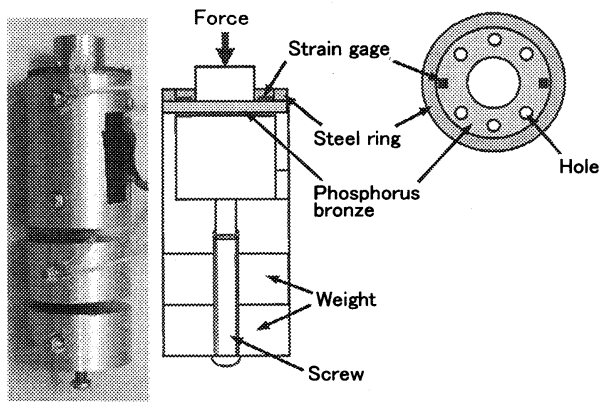

Fig. 3 A sensor to measure the impact force 
(株)から提供され，表 1 に示す。すべて自動車に使用 されているエアバッグ用のノンコート平織りの織物で ある. 繊維の原料は沸水処理済ナイロン 66 である.

また, 数值計算に必要な織物の力学特性は測定によ り得た ${ }^{(3)}$.

\section{3. 実験結果と考察}

$3 \cdot 1$ 衝撃力の測定周囲を固定した織物を圧縮 した空気によって膨らませ, 金属ブロックをある衝突 速度でそれに衝突させ，その衝撃力を $2 \cdot 1$ 項で提案し た装置で測定する。図 4 はその結果の一例で, エア夕

Table 1 Physical characteristics of airbag fabric samples

\begin{tabular}{|c|c|c|c|c|}
\hline $\begin{array}{l}\text { Type } \\
\text { No. }\end{array}$ & Material & $\begin{array}{l}\text { Yarn Linear } \\
\text { Density dtex } \\
/ \text { Filaments }\end{array}$ & $\begin{array}{l}\text { Ends } \\
\text { and } \\
\text { Picks/in } \\
\text { ch }\end{array}$ & Weave \\
\hline N4256 & $\begin{array}{c}\text { Nylon } \\
66 \\
\end{array}$ & $470 / 72$ & $55 \times 55$ & Plain \\
\hline N3562 & $\begin{array}{c}\text { Nylon } \\
66\end{array}$ & $350 / 73$ & $\begin{array}{c}63.5 \times \\
60.5\end{array}$ & Plain \\
\hline
\end{tabular}

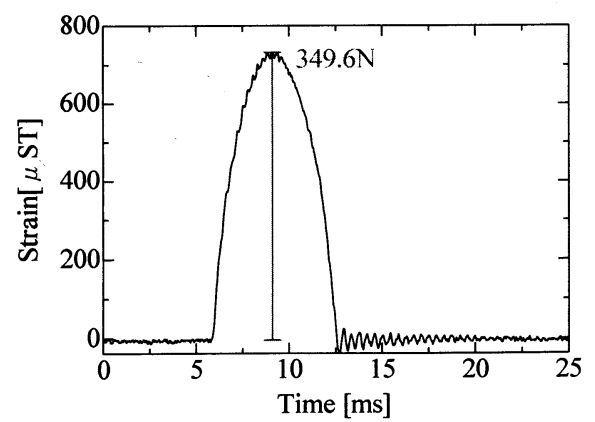

Fig. 4 Time-strain curve when a metal block collides to the air bag

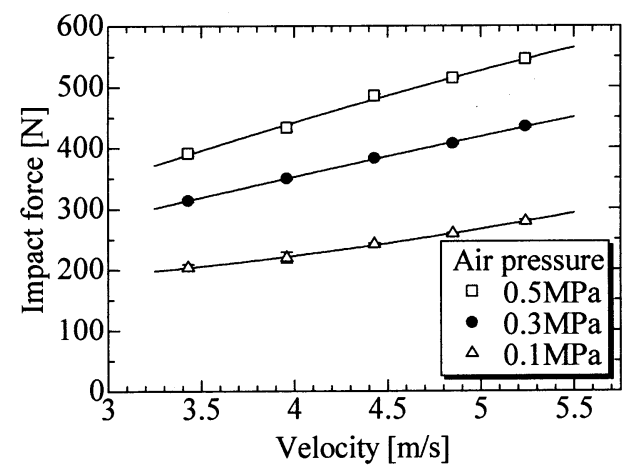

Fig. 5 Relationship between impact force and collision velocity (Sample: N 3562, Block mass : 0.225 $\mathrm{kg}$, Air pressure of the air tank: $0.1,0.3,0.5$ $\mathrm{MPa}$, Air tank volume: $9.42 \times 10^{5} \mathrm{~mm}^{3}$ )
ンクの圧力が $0.3 \mathrm{MPa}$, 衝突速度が $3.96 \mathrm{~m} / \mathrm{s}$ を設定 した際, 測定したセンサーのひずみと時間の曲線であ る.織物は N 3562 である。ひずみと時間の曲線に対 して，事前にセンサーのキャリブレーションで得られ た荷重とひずみの関係で換算し, 荷重-時間曲線を求 める. その曲線の最大值を衝撃力とする. 図 4 の場 合, 衝撃力が $349.6 \mathrm{~N}$ であることを示す. 同一条件 5 回の実験で得られたデータはほぼ重なり，ばらつきが 少ないことが分かった。

\section{$3 \cdot 2$ 衝突速度とエアタンク内部圧力の影響 夕} ンク内部圧力と衝撃力と衝突速度の関係を調べた. 図 5 はその一例である. 織物が N 3562, 金属ブロック質 量が $0.225 \mathrm{~kg}$, エアタンク容積が $9.42 \times 10^{5} \mathrm{~mm}^{3}$ で ある、図より, 衝突速度の増加にともない衝撃力が増 加することがわかった.これは, 衝突速度の増加によ って衝突時の金属ブロックの運動エネルギが増加する ためだと考えられる。

図 6 に衝突速度 $3.43,4.43,5.24 \mathrm{~m} / \mathrm{s}$ での衝撃力 とエアタンク内部圧力の関係を示す. 図より, エアタ ンク内部圧力の増加にともない衝撃力が増加すること を示している.これは, エアタンク内部圧力の増加に より，その圧力と釣り合う織物の張力が増加し，衝撃 力が増加するものと考えられる.

本実験範囲で, 各種の織物, すべてのタンク容積と ブロックの重さでの変化傾向は図 5 と図 6 と同じであ ることが確認された。

\section{$3 \cdot 3$ 金属ブロックの質量とエアタンク容積の影響} 2 種類の織物, 各種エアタンク容積において, 衝突速 度またはエアタンク内部圧力を変化させて測定を行 い, 金属ブロック質量が衝撃力へ及ぼす影響について 調べた。図 7 と図 8 はその測定の一例である。

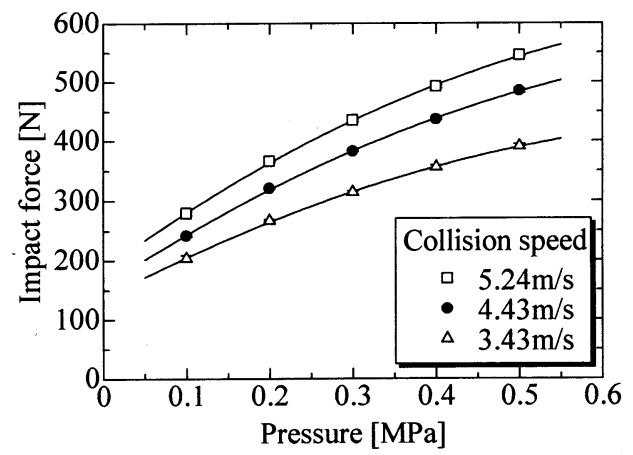

Fig. 6 Relationship between impact force and air pressure in air tank (Sample: N 3562, Block mass: $0.225 \mathrm{~kg}$, Collision speed : $3.43,4.43,5.24 \mathrm{~m} / \mathrm{s}$, Air tank volume: $9.42 \times 10^{5} \mathrm{~mm}^{3}$ ) 
図 7 は各金属ブロック質量に打ける衝撃力と衝突速 度との関係を示す. 織物が N 3562, エアタンク容積 が $9.42 \times 10^{5} \mathrm{~mm}^{3}$, エアタンク内部圧力が $0.3 \mathrm{MPa}$ である.図 8 は各金属ブロック質量における衝撃力と エアタンク内部圧力との関係を示す. 織物が N 3562, エアタンク容積が $9.42 \times 10^{5} \mathrm{~mm}^{3}$, 衝突速度が 3.43 $\mathrm{m} / \mathrm{s}$ である.

いずれの図においても, 金属ブロック質量の増加に ともない衝撃力が増加することがわかる.これは, 金 属ブロック質量の増加によって衝突時の金属ブロック の運動エネルギが増加するためと考えられる.

2 種類の織物, 各種金属ブロックの質量において, 衝突速度またはエアタンク内部圧力を変化させて測定 を行い，エアタンク容積が衝撃力に及ぼす影響につい て調べた．図 9 はその測定の一例である．各エアタン

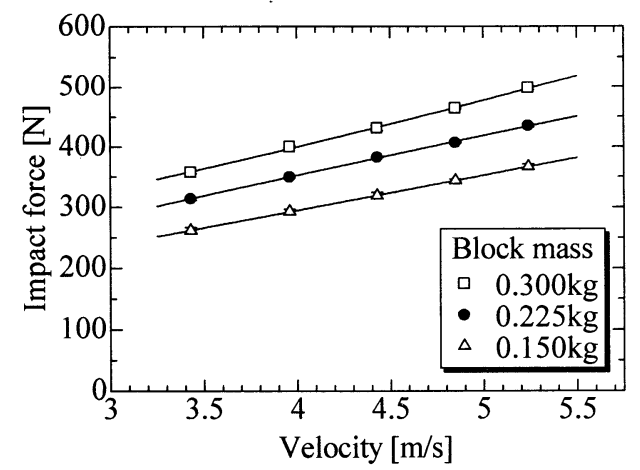

Fig. 7 Relationship between impact force and collision velocity in various block mass (Sample: N 3562, Block mass : $0.150,0.225,0.300 \mathrm{~kg}$, Air tank volume: $9.42 \times 10^{5} \mathrm{~mm}^{3}$, Air pressure : 0.3 $\mathrm{MPa})$

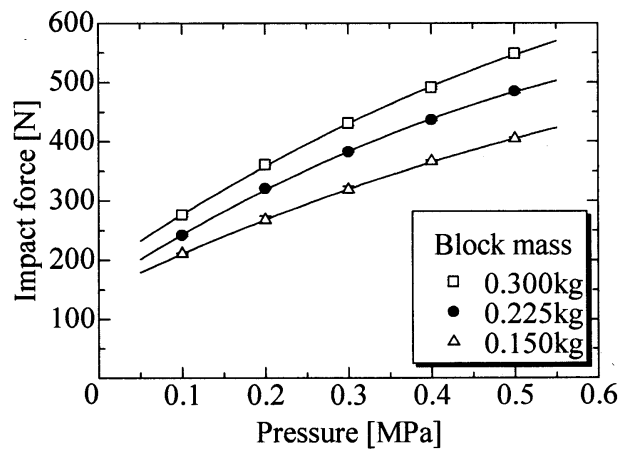

Fig. 8 Relationship between impact force and air pressure in various block mass (Sample: N 3562, Block mass: $0.150,0.225,0.300 \mathrm{~kg}$, Air tank volume : $9.42 \times 10^{5} \mathrm{~mm}^{3}$, Collision velocity : 3.43 $\mathrm{m} / \mathrm{s}$ )
ク容積における衝撃力と衝突速度との関係を示す. 織 物が N 3562, エアタンク内部圧力が $0.3 \mathrm{MPa}$ であ る.いずれにおいても，エアタンク容積の増加にとも ない衝撃力への影響は見られない.これは, 金属ブロ ックの織物展開面への押込み量に対してエアタンク容 積が大きく, 織物が変形しやすく, エアタンクにおけ る容積変化の効果が現れなかったためと考えられる.

しかし, エアタンク容積をさらに小さくした場合につ いて内部圧力の変化の影響が表れるものと考えられ， その場合の検討が必要である.

$3 \cdot 4$ 織物の力学特性の影響 各種金属ブロック の質量とタンク容積において, 衝突速度またはエアタ ンク内部圧力を変化させて測定を行い, 織物の種類に よる影響について調べた. 図 10 はその測定された結 果の一例である. エアタンク容積が $9.42 \times 10^{5} \mathrm{~mm}^{3}$,

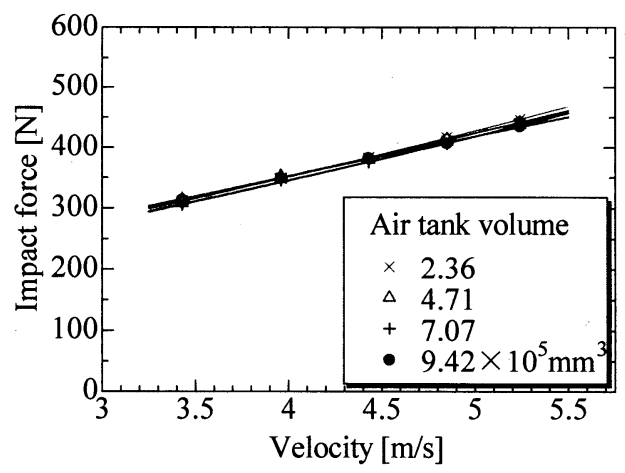

Fig. 9 Relationship between impact force and collision velocity in various air tank volume (Sample: N 3562, Block mass : $0.225 \mathrm{~kg}$, Air tank volume: $2.36,4.71,7.07,9.42 \times 10^{5} \mathrm{~mm}^{3}$, Air pressure: $0.3 \mathrm{MPa})$

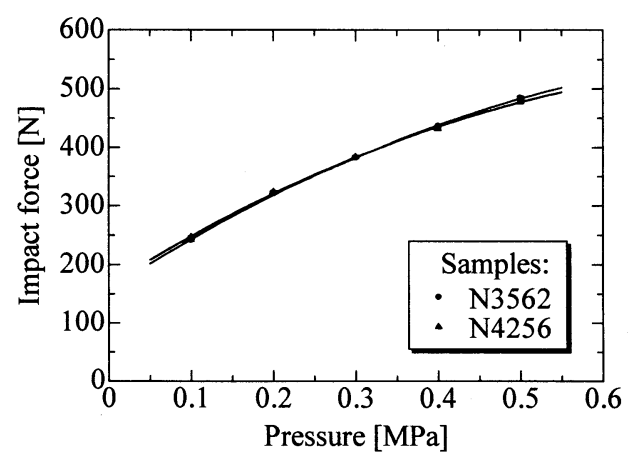

Fig. 10 Relationship between impact force and air pressure in various fabrics (Sample: N 3562 and $\mathrm{N} 4256$, Block mass: $0.225 \mathrm{~kg}$, Air tank volume : $9.42 \times 10^{5} \mathrm{~mm}^{3}$, Collision velocity : 4.43 $\mathrm{m} / \mathrm{s}$ ) 
衝突速度が $3.43 \mathrm{~m} / \mathrm{s}$, 金属ブロック質量が $0.225 \mathrm{~kg}$ である。

いずれにおいても，織物の違いによる衝撃力への影 響は見られない.これは 2 種類ともに現在自動車に使 用されているエアバッグの織物で, 前報(3) で示したよ うに 2 種類の織物の力学的特性が類似しているためだ と考えられる.

ここで, 織物の力学特性の影響を確認するために, N 3562 を 2 枚重ねた場合について測定し, 先に測定 した N 3562 の 1 枚の場合と比較した。図 11 はその 測定された結果である. 織物が 2 枚の場合で衝撃力が 大きくなっている.これは，2枚の場合では織物の剛 性が大きく, 伸びにくく, 緩衝作用が小さいためと考 えられる。これらより織物の特性は衝撃力に影響して いることを示している.

本実験装置は実際のエアバッグより小さく, 衝突物 に鼻など凹凸などを取り入れていないので，エアバッ グ展開によるけがを軽減させるため緩衝基礎デー夕と しては,さらに検討する必要がある.

\section{4. エアバッグ緩衝のシミュレーション}

圧縮空気によって展開された織物に一定速度を持つ 金属ブロックを衝突させ，その衝撃力のシミュレーシ ヨンを試みる。

前報(5)で提案した方法を利用して，エアバッグの織

Table 2 Mechanical properties of airbag fabric samples

\begin{tabular}{ccccc}
\hline $\begin{array}{c}\text { Type } \\
\text { No. }\end{array}$ & $\begin{array}{c}\mathrm{E}_{\mathrm{L}} \\
(\mathrm{N} / \mathrm{m})\end{array}$ & $\begin{array}{c}\mathrm{E}_{\mathrm{T}} \\
(\mathrm{N} / \mathrm{m})\end{array}$ & $\begin{array}{c}\mathrm{G} \\
(\mathrm{N} / \mathrm{m})\end{array}$ & $v_{\mathrm{LT}}$ \\
\hline $\mathrm{N} 4256$ & 103.86 & 48.95 & 2.10 & 0.682 \\
\hline $\mathrm{N} 3562$ & 82.34 & 58.57 & 1.99 & 0.795 \\
\hline
\end{tabular}

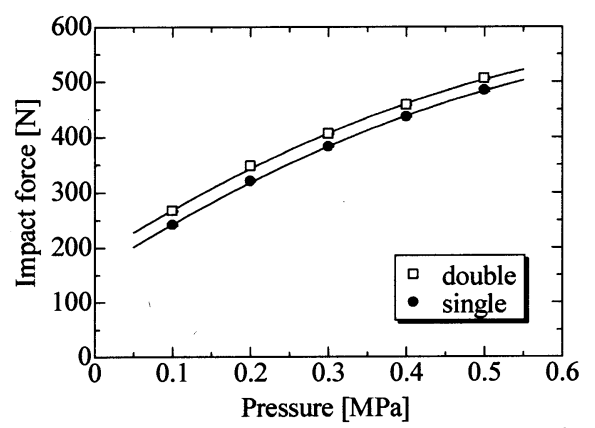

Fig. 11 Relationship between impact force and air pressure in single and double of fabrics (Sample: N 3562 , Block mass: $0.225 \mathrm{~kg}$, Air tank volume : $9.42 \times 10^{5} \mathrm{~mm}^{3}$, Collision velocity : 4.43 $\mathrm{m} / \mathrm{s})$
物を直交異方性平面膜として, 織物の主軸(たて糸と よこ糸)を $L, T$ 方向に扔ける面内合応力心゙クトル $\left\{N_{p}\right\}$ とひずみベクトル $\left\{\varepsilon_{p}\right\}$ の関係は式 $(1)$ で表す.

$$
\begin{aligned}
& \left\{N_{p}\right\}=\left\lfloor D_{p}\right\rfloor\left\{\varepsilon_{p}\right\} \cdots \cdots \cdots \cdots \cdots \cdots \cdots \cdots \cdots \cdots \cdots \cdots \cdots \cdots \cdots \cdots \\
& {\left[D_{p}\right]=\frac{1}{1-\nu_{L T} \nu_{T L}}\left[\begin{array}{ccc}
E_{L} & \nu_{L T} E_{T} & 0 \\
\nu_{T L} E_{L} & E_{T} & 0 \\
0 & 0 & G\left(1-\nu_{L T} \nu_{T L}\right)
\end{array}\right]}
\end{aligned}
$$

ここで, $E_{L}, E_{T}$ はそれぞれ $L$ 方向および $T$ 方向の見 かけの引張り剛性率 $[\mathrm{N} / \mathrm{m}], G$ は見かけのせん断剛 性 $[\mathrm{N} / \mathrm{m}]$ である. $\nu_{L T}, \nu_{T L}$ はそれぞれ $L$ 方向と $T$ 方向の見かけのポアソン比である.

織物の力学特性は前報 ${ }^{(5)}$ と同様, 実測で求めた.

本研究では大たわみ問題の解を, 三角要素分割によ る FEM と増分法を用いて求める.

まず，圧縮空気により膨らんだエアバッグの形状に 対して, 前報(5) のように, 先細ノズルの臨界流れ理論 を用いて, 膨らんだエアバッグ内の体積, エアバッグ 内とタンクとの空気圧力差などを考慮し, 断熱状態工 アバッグ内の圧力増加を算出し, エアバッグの形状を 計算する。指定された圧力に至るまでその計算を繰り 返す。

その後, 図 12 のモデルに示されたように展開され たエアバッグに金属ブロックを一定な速度で衝突させ

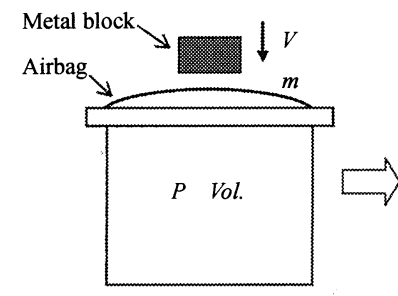

(a)

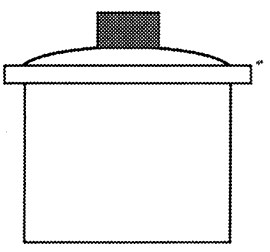

(b)
Fig. 12 Model of the airbag for shock absorbing

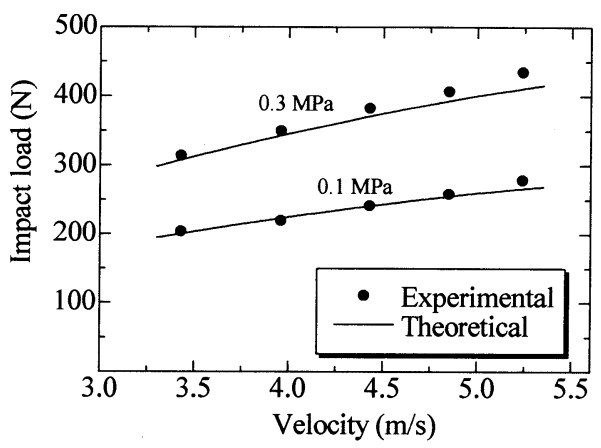

Fig. 13 Comparison between experimental value and calculative value 
ていく．織物の変位ベクトルを $\{u\}$ とすると，金属ブ ロックおよび織物の変位は次の式で示すことができ る.

$[m]\{\ddot{u}\}+[K]\{u\}=0$

ただし, $[K]$ は大変形剛性マトリクスと初期応力マト リクスを含めた剛性マトリクスである(5). $[m]$ は質量 マトリクスで，織物の慣性力を無視した．金属ブロッ クは剛体とする。

金属ブロックと接触部分のエアバッグの抗力は衝撃 力とし，前報(5) で提案した方法で計算する．織物への ブロックの押込みより，エアバッグ内の体積が変化し， 断熱状態を仮定したエアバッグ内の圧力増加を算出し た。式 (2)を用い, 直接時間積分の陽解法により, 各 時間増分間で収束するまで反復計算する。

図 13 はその計算結果の一例である. 織物サンプル は N 3562, 金属ブロック質量が $0.225 \mathrm{~kg}$, エアタン ク容積が $9.42 \times 10^{5} \mathrm{~mm}^{3}$, エアタンク内部圧力が 0.1 , $0.3 \mathrm{MPa}$ である. ○測定值である。実線は本研究 で提案されたモデルで計算されたものである。高い速 度部分で若干誤差があるものの，計算値と測定值はほ ほ傾向が一致しているので，シミュレーション方法の 有効性が確かめられた。

\section{5. ま と め}

エアバッグの緩衝に関する基礎デー夕を収集するた めに, 物体がいろいろな条件での展開した布に衝突す る際の衝撃力を測定できる装置を考案し, 試作した. 2 種類のエアバッグ用の織物を用いて, 織物内の衝突 速度などいろいろな条件を変化させ, 衝撃力への影響 を調べた。

衝突速度の増加にともない衝撃力が増加する.エア タンク内部圧力の増加にともない衝撃力が増加する. 衝突物体(金属ブロック)質量の増加にともない衝撃力 が増加する。ただし本実験の範囲では，エアタンク容 積の衝撃力への影響は見られなかった。織物の特性が
衝撃力に影響していることが分かった。

また, 文献 ( 3 ) で提案した計算法を利用して, エア バッグの緩衝特性をシミュレーションした。試作した 装置を用いて測定した結果は, 計算結果と一致し，そ の有用性が確認できた。

本研究で協力をいただいた豊田紡織(株)と東洋紡 (株) に謝意を表します。また，本研究前期段階の仕事 に参加した当時信州大学大学院生の若林康郎君にお礼 を申し上げます。

本研究は文部科学省科学研究費補助金 (COE 形成基 礎研究費；10 CE 2003）および [ (C)（2 )1155507000]の補助を受けて行った。

\section{文献}

(1) Simamura, M. et al., Injuries of car drivers depending on with or without Srs airbag In-depth accident study, Spring Meeting of the Society of Automotive Engineers of Japan, 20005270 (2000).

(2) Oyama, M., A consideration of air bag deployed cases in collisions, JARI Research Journal, Vol. 20, No. 3 (1998), pp. 20-26.

(3) Arai, Y. and Tateishi, K., Comparison of injuries to male and female occupants in real-world automobile accidents, JARI Research Journal, Vol.24, No.9 (2002), pp. 13-16.

(4) Bao, L., Sakurai, M. and Kemmochi, K., Measurement of Impact Force when Airbag Inflates at High Speed, Transactions of the Japan Society of Mechanical Engineers, Series C, Vol. 72 (2006), pp. 2214-2218.

( 5 ) Bao, L., Takatera, M. and Kemmochi, K., Effect of Mechanical Properties of Fabrics on Impact Force, Transactions of the Japan Society of Mechanical Engineers, Series C, Vol. 73, No. 12 (2007), pp. 3193-3197.

(6) Harris, M. and Crede, E., Shock and Vibration Handbook, (1990), McGraw-Hill.

( 7 ) Bao, L., Umeda, D., Sakurai, M. and Kemmochi, K. Shock Absorbing Characteristic of Laminated FRP Cylinder, Transactions of the Japan Society of Mechanical Engineers, Series C, Vol. 71 (2005), pp. 380-385.

(8) Fukaya, K., Study on Usage of Safety Belt and Scope of Airbag for Fall Protection, Research Reports of the National Institute of Industrial Safety, NIIS-RR-2002 (2003), pp. 95-104. 